\title{
"Perchance to dream". Personality modifications and criminal liability : a nineteenth-century debate between psychiatry and law
}

Paolo Marchetti

\section{(2) OpenEdition \\ Journals}

Electronic version

URL: http://journals.openedition.org/chs/1600

DOI: $10.4000 /$ chs. 1600

ISSN: 1663-4837

Publisher

Librairie Droz

\section{Printed version}

Date of publication: 1 November 2015

Number of pages: $77-91$

ISBN: 978-2-600-01908-8

ISSN: 1422-0857

\section{Electronic reference}

Paolo Marchetti, «"Perchance to dream". Personality modifications and criminal liability : a nineteenthcentury debate between psychiatry and law », Crime, Histoire \& Sociétés / Crime, History \& Societies [Online], Vol. 19, n² | 2015, Online since 01 November 2017, connection on 04 May 2019. URL : http:// journals.openedition.org/chs/1600; DOI : 10.4000/chs. 1600 


\title{
"Perchance to dream" Personality modifications and criminal liability:
}

\author{
a nineteenth-century debate between psychiatry and law
}

\section{Paolo Marchetti}

At the end of the nineteenth century, psychiatry 'discovered' some new pathologies such as split personality. These pathologies put into question the traditional reassuring image of human beings as capable of fully controlling his/her behaviour. The aim of this article is to cast new light on how the discovery by psychiatry of certain mental disorders questioned the unitary vision of the human mind previously shared and accepted by legal theory and medical sciences. Certain psychiatrists maintained that some actions seemed to be determined by unconscious forces within an individual, even without any obvious mental illness. These observations challenged the concept of legal liability which had previously been accepted by most legal scholars, and gave rise to a lively debate between medicine and law.

À la fin du XIX siècle, la psychiatrie 'découvrit' quelques nouvelles maladies, comme par exemple la double personnalité, lesquelles mettaient en question l'idée, rassurante, d'un être humain maître de soi. Cet article essaie de mettre en évidence comment l'émergence de ces troubles du comportement semblait ébranler la vision unitaire de l'homme, que le droit et la médicine se devaient jusque-là de partager. D'après certains psychiatres, même dans le cas des maladies mentales non déclarées plusieurs actions du sujet semblaient être conditionnées per ses forces inconscientes. Ces remarques se heurtèrent à l'idée de la responsabilité juridique affirmée par la plupart des juristes et donna lieu à un débat houleux entre médecine et droit.

\section{DOUBLE PERSONALITY AND CRIMINAL LIABILITY : THE FELIDA X CASE}

Gelida was a girl from Bordeaux. Intelligent, anxious, and melancholic. In

1858, when she was fourteen, she began to show strange behavior. She would fall into sudden torpors from which she could not be roused. Later she would wake up again and her personality seemed totally changed. She appeared more goodhumored and extrovert. But this state - that Eugène Azam later described as her 'second condition' - would last only for a few hours. In the same way as her new

Paolo Marchetti is full professor of Legal History at the University of Teramo (Italy). He has published major works on the history of penal law and Criminology: L'armata del crimine. Teoria e repressione della recidiva in Italia, Ancona, Cattedrale, 2008; 'Le "sentinelle del male". L'invenzione ottocentesca del criminale nemico della società tra naturalismo giuridico e normativismo psichiatrico', in Quaderni fiorentini, 2009, 38, 2, pp. 1009-180; L'Inconscio in tribunale. Azioni incoscienti e diritto penale. Da Charcot alle neuroscienze, Milano, Franco Angeli, 2014. 
personality had shown itself, it would go away, and the previous Felida resurfaced. The phenomenon repeated itself regularly on a daily basis. Over the years, the periods during which the girl fell into her 'second state' grew longer, until they lasted for several months. The strange fact is that the two personalities communicated in an asymmetric way. Felida, when in her 'second condition', remembered all that had happened in her normal state, but when she came back to her ordinary self she had absolutely no memory of what had occured in her parallel existence. Nevertheless, under both conditions the psychological state of the girl did not demonstrate any alteration. Her mind was intact, only her character was different.

The Felida case is one of the best known and quoted in medical literature between the nineteenth and twentieth century. Every book that deals with personality alteration refers to this case in a more or less detailed form. This is the case to which Eugène Azam (the physician who treated her for a long time) owes his fame. Without Felida (to be more precise, Felida X, as Azam called the girl) it is very probable that no one would have remembered the name of this otherwise obscure physician from Bordeaux.

Azam brought the clinical history of this young girl to public attention in 1876 through an article published in the Revue scientifique. ${ }^{2}$ He would treat the same case again, several times, until the publication in 1887 of the volume entitled Hypnotisme, double conscience et altérations de la personnalité in which the story of Felida occupies most of the pages. ${ }^{3}$

Even if the Felida case is not the first of which the public has knowledge, ${ }^{4}$ the subject of split personalities, after Azam's work, begins to be studied in depth by contemporary psychiatry, in spite of some initial mistrust, ${ }^{5}$ and not only by psychiatrists, because the subject of the 'double' became a fashionable narrative in late nineteenth-century literature. Some novels (among which the Strange Case of Dr Jekyll and Mr Hyde by Robert Louis Stevenson represents the best known tale) made use of this odd pathology to invent stories capable of arousing public curiosity. ${ }^{6}$

The importance of this stylistic mixture between description of clinical cases and literary fiction cannot be totally ignored. The narrative of the bizarre existential vicissitudes that involve the life of several patients seems to correspond to a literary dimension that reached its high point in the really successful narratives of clinical cases under Freudian analysis, which are written as if they were detective novels. In a similar vein, but with a changed point of view, fictional literature, which was

\footnotetext{
Azam (1876).
}

Azam (1887).

4 On the Felida case see Carroy (1992). The cases of split personality known in the scientific literature before Felida are related by Hacking (1996). On Felida and the following cases of split or multiple personalities see pp. 222sq. On this matter please see also Carroy (2001, pp. 39-49) and Carroy (2001, pp. 43-73).

5 On the renewed interest that psychiatry has shown to pathological dissociation that were being included into the nosographic category, see Fornari (2008, pp. 347sq.).

6 Mintorn (1880); Lindau (1893); Hennique (1899); Claretie (1908). Charles Richet, the 1913 Nobel prize-winner for medicine, published (under the name of Charles Epheyre) two novels about the themes of split personality and hypnotism: Epheyre $(1889,1887)$. On this subject see Carroy (1993); Herdman (1990). 
inspired by this kind of psychiatric vicissitudes, would often take the form of a clinical case. ${ }^{7}$

Beyond this charming confusion of genres, we have to point out that in the medical literature of that period (as well as in the legal literature), the story of the case - or cases - under consideration assumes a primary role in the author's narrative strategy. The case stories were called upon not only to uphold and support the scientific hypothesis under discussion, but became themselves an integral and unavoidable part of an elaborate reasoning that would have become ineffectual and lightweight, if deprived of their literary dimension. Moreover, a case story would be referred to countless times by all authors writing on the same issue, thus giving to the modern reader a sense of boredom by being presented with the same facts, if not the same words. Still, in spite of the 'seriality' of case histories, the narrative of the most sensational episodes referred to by the specialized literature at that time is inevitable for whoever is interested in reconstructing, from a historical point of view, the conceptual universe that links itself to these small clinical or experimental dramas. The stories of these petty existential vicissitudes were the indispensable mental framework that comes to life behind their development.

There is another reason that makes the case of Felida $\mathrm{X}$ very interesting (or, at least, makes it interesting in relation to the discourse dealt with in these pages). Azam did not need long time to realize that the strange behavior of his patient constituted an authentic dilemma, not only for medical science at that time. The curious existence of Felida posed serious questions in juridicalterms, in particular with regard to the question of penal liability. ${ }^{8}$ Indeed, if the ill-fated girl (or every other person in her situation) committed a crime in her 'second condition', would she be called to answer for it in court? The problem raised by Azam was not without foundation. If not considered thoroughly, one might be forced into the absurd conclusion that a person could be punished for behavior of which he or she had no memory at all; behavior that could be linked to this person only in the material sense. This would lead towards obscruing the deeper logic of penal punishment which, by common opinion, consisted of retribution by the community against the person guilty of acting against the rules of civil coexistence, as well as functioned as deterrence against repetition of the act by the condemned person.

To provide an answer to this question, Azam consulted several judges and legal scholars from Bordeaux who answered, in general, that the criminal responsability of such a subject had to be considered with leniency. After all - and this was the argument of one answer that Azam quoted in full - in both conditions Felida maintained her mind intact and her actions were led by conscious will; both these were the necessary and sufficient conditions for considering a subject legally responsible, even with diminished responsibility. The anonymous lawyer quoted by Azam did not deny that the case was not easy to solve. For instance, there were crimes such as misappropriation in which the awareness of the things belonging to a different person was an indispensable condition for the punishment of the offender. And in this case, the total absence of memory had to play a key role in any case for innocence. The legal expert did not deny that many psychiatrists disputed the idea of

See Revel, Passeron (eds) (2005), with particular reference to Carroy (2005, pp. 201-228) and Ferrari (1985). For the legal literature see the several essays collected in Schönert, Imm, Linder (eds) (1991).

8 Azam (1887, pp. 184sq.). 
partial mental illness. For these psychiatrists the profound alteration of some mental faculties necessarily affected the whole psyche of the person. Like the majority of his colleagues, the author of the reply was inclined to recognise reduced liability for an individual who had committed a crime while in this condition. Nonetheless, he suggested leaving the resolution of the specific judicial problem to the judge who would consider it on a case-by-case basis.

However, these conclusions did not obtain a general consensus. ${ }^{9}$ Azam himself shared in his book the opinion of Jean-François-Charles Dufay who, with reference only to Felida's case and on the question of split personality, declared himself in favour of complete legal irresponsibility of the persons suffering from such a pathology, irrespective of the condition of personality at the moment of the crime. ${ }^{10}$ After all, the French physician and politician asked himself how it was possible to establish which of the various personalities of an individual was normal and which pathological. It was hysteria that dominated the whole existence of these persons and for this reason they had to be declared mentally ill, thus unaccountable in legal terms.

\section{2. "IS IT TRUE OR AM I DREAMING?" THE CRIMINAL SLEEPWALKER}

The first answer to the question posed by Azam concerning the criminal liability of Felida relates to the state of sleepwalking. It is precisely the state of sleeping and dreaming that allowed us to get insight into the phenomenon of split personality with some degree of cohesion - at least at the psychiatric level. Yet, as Foucault writes, the equation of madness/dream was proposed by Jules Baillarger already by the mid-nineteenth century and at that time this position caused a radical change in the epistemological organization of psychiatric science. ${ }^{11}$ Baillarger asserted that the element that characterized the behaviour of a madman was the fact of living in a dream-condition. But in this state, the problem stemmed from the lack of free will, rather than the person acting with a distorted sence of reality. As a source of involuntary processes, the dream became the model for every mental illness, thus moving the focus of the diagnosis of mental illness from balancing truth against untruth, as was the previously accepted psychiatric approach, to a question about voluntary or involuntary action. ${ }^{12}$

In this context, the recourse to the dream acted out by the sleepwalker represented not only the point of reference where the phenomenon of split personality was anchored (Azam defined Felida a "total somnambulist"13), but also designated every

9 Georges Gilles de la Tourette remembered how, during the Congress of the French Association for the Development of the Sciences in Paris in 1878, the issue had been discussed in detail and they had not found a common point of view concerning criminal liability of a person suffering from split personality (Gilles de la Tourette, 1889, p. 257).

10 Azam (1887, pp. 190sq.). The issue has been discussed by Dufay in an article which appeared in the Revue Scientifique in 1879.

11 On the relationships between dreams and madness in nineteenth-century psychiatry see James (1995). See also Carroy (2012, pp. 53sq.).

12 Foucault (2007, pp. 147-148).

$13 \operatorname{Azam}(1887$, p. 185). 
other state of alteration in the personality. The hypnotic practice itself was defined as "induced somnambulism", almost as if the psychiatrists wanted to emphasise the common roots of behaviors that led the person towards a conduct beyond the control of free will, which could only be deciphered with reference to a kind of dream automatism. This opinion was stressed by Jules Liégeois, the French jurist who devoted himself most fully to the subject of personality modification and its implications in law. According to Liégeois, people like Felida, when passing into the 'second condition', would enter a kind of sleep, which was characterised by having all the appearances of the state of being awake. And for this reason they could not be considered responsible for their actions, at least, not for those ones done within the 'second condition'. ${ }^{14}$ The same thing happened for individuals under hypnosis. Liégeois asserted that, after all, the sleepwalker like the hypnotized subject was a dreamer. The only difference between the two conditions was that the natural sleepwalker did not receive orders from the outside world, and his will was not forced by any alien strength. On the contrary, in the artificial sleepwalker it was possible to seize his will and thereby direct his actions. ${ }^{15}$

Of course, the phenomenon of split personality posed more complex problems in the medical-legal sphere than those arising from somnambulism. Azam himself did not to share the opinion of Dufay, who argued that people who showed signs of split personality were in fact suffering from hysteria, and therefore they could not be considered accountable for crimes they might commit - whether in the first, or in the second condition. Azam wrote that Dufay's position was untenable, if nothing else, due to the fact that a great number of women were affected by hysteria, and it was not viable to acquit them all on the grounds that they were mentally incapable. ${ }^{16} \mathrm{~A}$ lot of doubts centered around the problem of the relationship between the first and the second personality. A lot of authors asked themselves whether it was possible always to consider the first as the normal condition, given that, in many cases, the modified state of the personality lasted much longer than the first condition. ${ }^{17}$ In spite of these perplexities, it was nevertheless somnambulism that was to become the paradigm for references to the phenomenon of split personality in the medical-legal discourse. After all, the issue concerning crimes committed in the sleepwalking state was a subject to which law and moral philosophy had long had to find practical solutions. ${ }^{18}$

The recognition that sleepwalkers could not be held legally responsible did, in fact, not come about without conflict. At the beginning of the nineteenth century two prominent authors like François-Emmanuel Fodéré and Johann Cristoph Hoffbauer had expressed several perplexities on this point. The former had excluded the liability of the sleepwalker only in the case in which his/her behavior was the consequence of an illness. In the absence of any medical condition, the sleepwalker's action had to be considered the fruit of bad principles and malicious ideas that the person supposedly cultivated while

\footnotetext{
Liégeois (1889, pp. 611-613).

15 Liégeois $(1889$, p. 439).

16 Liégeois (1889, p. 201).

17 Gilles de la Tourette $(1889$, p. 258)

18 Alimena (1896, vol. 3, pp. 122sq.).
} 
awake, and for this reason he/she could be not excused from any reproach. ${ }^{19}$ For Hoffbauer, the sleepwalker's liability did not originate from the integrity of a person's intelligence, but because he/she had not taken the necessary steps to prevent harmful events, although being fully aware of his/her condition ${ }^{20}$. During the nineteenth century these positions (influenced without any doubt by the legal tradition of the Ancien Régime and linked to a unitary view of the human personality) lost their importance, even if they continued to have some isolated supporters. ${ }^{21}$ One was Claude Joseph Tissot, who argued that if a sleepwalker killed a sworn enemy, he/she must be punished, although with a lighter sentence. ${ }^{22}$ Similarly Joseph Briand maintained that liability, or at least culpability, could not be excluded a priori. ${ }^{23}$

In any case, the sleepwalker's behavior was, in the medical discourse, increasingly compared to that of an individual whose actions are directed by automatic impulses which he/she was incapable of resisting. On the basis of these conclusions, it was generally recognised that the sleepwalker could be punished for his/her acts. In the final decades of the nineteenth century, psychiatry often resorted to this theory of automatisms to make sense of a number of hardly explicable criminal deeds. Or better still, the sleepwalking paradigm was used to define several states of torpor of the consciousness that seemed to take on the aspect of a real animated dream.

So, criminal deeds, committed by persons in somnambulistic condition, entered into the courtrooms with some emblematic cases, that were repeated countless times in the medical and legal literature of those years. One of these was the case of young D., arrested in France for offences against decency and sentenced to three months in prison, who was saved at the last minute by Dr Auguste Motet. In fact, during the appeal hearing, Motet wrote a report based on his psychiatric examination for the defendant which aimed at showing that the defendant was in a state of unconsciousness at the moment of the deed against decency. Motet had known the young man before at the Saint-Antoine hospital, where his colleague Ernest Mesnet used to hypnotize him. But the two policemen who arrested him persisted in considering that D., at the moment of his arrest, was consciously committing an act against decency. The public prosecutor himself, developing his conclusions, recognised that the subject sometimes lived in a mental state where consciousness was absent, but did not consider that this condition was proved to be present at the moment when the defendant was seen by the two representatives of the law. At this moment Motet asked for permission to perform an experiment to show the defendant's liability to be influenced by the Court. So, the judges and the lawyers retired into a secluded room and watched a real show put on by the expert physician. After having hypnotized D., Motet asked him to repeat the same gestures that he was performing at the moment he was arrested. D., obviously in a state of trance, did not hesitate to unbutton his

\footnotetext{
19 Fodéré (1813, vol. 1, pp. 256 sq.).

20 Hoffbauer (1827, p. 169). Esquirol and Itard, annotating the French edition of Hoffbauer's book here quoted - asserted that, during the awake state, some thoughts could find their realization in the somnambulistic phase. For this reason the sleepwalker could not be treated leniently by the criminal justice system (p. 171).

21 About this subject see Alimena (1896, p. 124).

22 Tissot (1860, vol. 1, p. 40).

23 Briand (1821).
} 
trousers. The defendant was immediately stopped, but this was enough to acquit him of the charge for which he had been convicted at the lower court. ${ }^{24}$ Another case was that of a young thief (studied by Ernest Mesnet) who was arrested after being caught stealing some furniture from a shop close to his home. Despite being caught in the act, he protested his innocence, but his behaviour was manifestly incoherent. Even during questioning, the attitude of this thief seemed bizarre. For this reason the police sent him to the Hotel-Dieu, which at that time was under the leadership of Mesnet. The physicians who had him under observation immediately realised that the young man was often seized by attacks of somnambulism, during which he even contemplated suicide. At this point, it was Mesnet himself who forced him to undergo several hypnotic experiments from which Mesnet came to the firm belief that in presence of particular conditions the subject lost his own will and became a blind tool for any idea that dominated him. ${ }^{25}$ Finally there was the case of the girl from Macerata in Italy, Teresa G., who had killed her son in a somnambulistic fit, but was acquitted because she was considered absolutely lacking any capacity to control her will at the moment of the crime ${ }^{26}$ And this story, with all its human tragedy was related in the specialized literature at that time to reassert the principle of total irresponsability of the sleepwalker in relation to crimes committed during the somnambulistic state. ${ }^{27}$

\section{PATHOLOGIES OF THE WILL AND THE QUESTION OF CRIMINAL RESPONSIBILITY}

Let us leave the case of Felida and other medical cases in the background for the moment to broaden the field of observation of our analysis. From the medico-legal perspective, the problems arising from a phenomenon like split personality are of considerable importance, but we are only able to understand them if we put them into a wider context.

At the beginning of the nineteenth century, psychiatric science had started to develop its observations by continually engaging with the legal world. The area where the two disciplines tended to overlap was not just that of liability over the definition of the border between normality and anormality. As Michel Foucault said, during this century psychiatry tended to develop increasingly towards legal medicin. Its analyses continuously fluctuated between the description of proper conduct and the medical analysis of abnormalities. It developed, essentially, into a science and technique of identifying abnormal behavior, thus establishing a link between crime and madness. From that moment, the connection between crime and mental illness no longer delinated the outer limits of the sphere of psychiatry, but rather one of its core concerns. ${ }^{28}$ Beyond this observation, medicine and law converged and often came into conflict just over the topic of liability. Again, the birth of a discipline like criminology - an original product of the last decades of the nineteenth-century -

\footnotetext{
Motet (1881).

25 Mesnet (1887).

26 Lapponi (1883) (before published in Bollettino delle scienze mediche di Bologna, 1883, 10).

27 Gilles de la Tourette (1889, p. 211); Liégeois (1889 p. 595).

28 Foucault (2007, p. 147-148). See also Marchetti (2009).
} 
only becomes understandable as part of a process of constant interaction between different fields of knowledge (notably medicine and law) and their diverging approaches to the question of liability. ${ }^{29}$

In any case, the identification of new pathologies, that clashed with the way in which alienists of the ancien régime had traditionally secluded the space of mental illness, made the problem of criminal liability more complex. After all, medicine and law had no points of friction until medical science began to consider mental illness as a temporary or permanent absence of the faculties of reason. The 'madman' was an easily recognizable subject (even by whoever did not have particular clinical skill) because his reasoning and behavior showed themselves lacking any connection with reality. However this conception of mental illness was confronted with a lot of problems when strange pathologies like monomania, and later 'moral insanity', became the object of observation and research in psychiatric science. In these cases, it was not so difficult to realize that, despite the examined subjects having an intact mind, he/she were unable to restrain his/her impulses to commit actions contrary to the norms of behavior whose social value was generally accepted.

All over France a debate developed on the topic of monomania. Over time people lost interest in this phenomenon and it was replaced by debates on 'moral insanity'. ${ }^{30}$ This is the most obvious evidence of the fact that legal categories were inadequate to provide an exact position on criminal responsibility in relation to certain behaviors whose psychiatric nature was not easy to grasp. ${ }^{31}$ According to Article 64 of the French Penal Code, which inspired almost all the penal legislation in continental Europe, "There is no crime nor punishment if the defendant was in a state of madness when he committed the action, or if he was pushed by a strength to which he was unable to resist". The Penal Code thereby defined the terms of individual responsibility and established a close correlation between responsibility and rationality. ${ }^{32}$ In this context, behavior like that of the monomaniac (characterized by a lack of delirium and a peculiar clearness of mind) seemed to go beyond the application of the rule. Even considering that the mentioning of the "irresistible strength", to which the article referred, was generally intended as external irresistible strength, and this to avoid that the argument for legal non-accountability could be invoked to justify crimes of passion. But psychiatric science moved in the direction of recognising the full pathological nature of monomania, while abandoning even the notion of partial insanity that had initially characterized descriptions of this illness. ${ }^{33}$ In this sense mental illness was understood as localized in a symptom, that could happen only to a totally insane person. ${ }^{34}$ This conclusion placed itself in opposition to several legislative proposals in order to allow reduced criminal liability and therefore punishability with regard to the partially insane. ${ }^{35}$

\footnotetext{
$29 \quad$ Harris (1988, p. 3).

30 About this subject see Fornari (1997, 1988); Babini (1982, pp. 153-154).

31 On this subject see the article published by Carlo Livi concerning monomania and sent "A' giurisperiti piuttosto che a' medici" (Livi, 1876, 2, pp. 394-415 and 639-660).

32 Castel (1980, chap. 3 and 4).

33 See Tamassia (1876).

34 Foucault (2007, pp. 142-143).

35 As in the case of the Italian penal code of 1889, Babini (1982, pp. 153-154).
} 
In the 1880s, the subject of monomania was almost completely marginalized from scientific discourse and the issue of moral insanity took centre stage. Also on this new pathology, were medicine and law unable to speak the same language. Moreover psychiatric science faced difficulties agreeing on the nature of the behavioral disorder itself, ${ }^{36}$ and this pathology appeared hardly definable in judicial terms. The morally insane man was a lucidly malicious person, aggressive, violent, lacking in moral scruples and insensitive to common human sentiments. His mind, in other words, remained totally intact, even if he was unable to control his behavior through of his will. But also in this case, justice invariably asked the same question to medical science, as it wanted to know whether the morally insane person was responsible for his own actions, thus identifying a boundary between the criminal and the non-responsible person.

The sense of disorientation that the "discovery" of these new psychiatric pathologies produced in the juridical sphere is demonstrated by the difficulties that the legislators, who were involved in reforming the penal law in many European countries, faced in their attempt to provide an adequate legislative form to the topic of criminal liability. None of the established definitions seemed suited to give the right importance to the role that the will (in its various abnormal expressions) had in the beginning and in the full manifestation of pathological behaviors. As Carlo Livi reminded us in an article published in the Rivista sperimentale di freniatria in the $1877,{ }^{37}$ the forms proposed until then did not consider one of the central elements of madness, that is to say, the loss of ability by the affected person to control his/her own will. According to Livi, whoever tried to reassert the loss of reasoning as an exclusive and central criterion on which to assess whether a person could be held criminally responsible, reaffirmed past prejudices which proposed that the premeditation and the preparation of a crime always involved culpability, not realizing that the essence of madness lay in a lesion of the will rather than of the consciousness. The admonishment of Livi did not seem totally unwarranted, given the difficulty of Italian psychiatry in persuading judges about the pathological nature of certain forms of behaviour that seemed more the fruit of lucid malevolence than of a diseased mind.

Livi's worry did not only involve Italian psychiatry. Krafft-Ebing himself used a lot of pages of his Treatise of forensic psychopathology (a Bible of forensic medicine at that time) to confute several opinions that circulated concerning the symptoms of madness; opinions which he suggested had long been the base for diagnosis or the suspicion of insanity ${ }^{38}$ Livi was thus refuting the idea that the action of a madman never had a reasonable and specific cause, unlike the healthy person. He also objected to the opinion that certain actions could be isolated in the life of a man, in contrast with all the other displays of his behaviour. Similarly with the notion that the "crazy" action excluded, by its nature, premeditation, calculation and caution ploy, as well as awareness of his/her own guilt and repentance, or the idea that individuals in a state of madness were incapable of carrying out reasoned discours.

The reference to Carlo Livi and to the Italian medical-legal science is not fortuitous. Since Italian national unification in 1861 an intense debate had developed

\footnotetext{
36 About the Italian debate on moral insanity see Babini (1982, pp. 167sq.)

37 Livi (1877).

38 Krafft-Ebing von (1897).
} 
about reform of the penal code that ended only in 1889 , when the "Zanardelli code" was promulgated. Thus Italy may be considered an interesting laboratory for penal law in the European context. ${ }^{39}$

In any case, even if legislators in Italy arrived at the formulation of an article (article 46 of the Penal Code of 1889) in which they distinguished between awareness and will of an action, without emphasizing the controversial notion of free will, ${ }^{40}$ the legislative openness to these new positions of psychiatric science was very cautious. In fact, in some way, it left unsolved the main issues that medical science of the late nineteenth century had opened some decades before This shows how hard it was for the law to accept the pathologization of an aspect of human life such as the will, for which the psychiatric categories remained largely inconclusive.

This short analysis reveals the difficulties that law, more than medicine, faced in evaluating the volitive function as a fundamental element of criminal liability. This allows us to understand how difficult it was to approach a case like that of Felida X with legal concepts. Similarly in cases of split personality where the mental faculties remained intact, while even the capacity of these persons to decide seemed not to be injured in any essential way. At most, it was necessary to decide what was the core of the personality to which one might attribute responsibility for any criminal act. And this problem was closely linked to that of establishing whether an abnomality, such as split personality, could be considered a behavioural disorder that comprehensively damaged the mental faculties of the person who suffered from it. After all, as Krafft-Ebing, speaking about the role assigned to the examining physician in trials involing such cases, asserted that the function of the psychiatric examination was not to express a judgment on "responsibility [nor] free will, but [on] the determination of the integrity or of the mental illness, by means of scientific analysis". ${ }^{41}$

From this point of view, the attempt to define a clear demarcation line between health and madness was a task with which psychiatric science engaged throughout the better part of the nineteenth century. And the obsession of Cesare Lombroso for discovering some biological and behavioral marks that could determine beyond any doubt the difference between normality and abnormality was only a reflection of a more general trend. ${ }^{42}$

Beyond appearances, however, even this issue met with several difficulties. Modern psychiatric science, from the very beginning, ran into a problem which was not easy to solve. According to Esquirol - who, with his master Pinel, can be considered at the origin of the definition of a new disciplinary dimension of psychiatric science - it was impossible to clearly distinguish the condition of the 'madman' from that of the healthy man. Between the two tendencies existed a line of continuity. It is true that this idea of a continuum between normality and insanity was almost immediately denied by Georget, the most highly regarded pupil of

\footnotetext{
$39 \quad$ On this subject see Sbriccoli (1998, pp. 487-551).

40 "He who is not punishable, at the moment he committed the action, was in such a state of mental illness as to deprive him of the consciousness or the will of his own acts". On the origins of article 46 and regarding the influence that the Tuscan penal culture had on the final wording of the rule, see Dezza (1991, 21, 1, pp. 131-158, now in Id., Saggi di storia del diritto penale moderno, Milano, Led Edizioni Universitarie, 1992, pp. 281-316).

41 Krafft-Ebing (1897, p. 27).

42 About Cesare Lombroso see Marchetti (2012a, pp. 366-370, 2012b, pp. 69-96).
} 
Esquirol, who developed his discourse about insanity by complying with a strictly physiological concept of mental illness. But it is also true that Georget himself was not entirely capable of reversing this 'scandal' sparked by the assertion that there was a line of continuity between normality and madness. Accordingly this kind of heuristic perplexity characterized psychiatric knowledge (even if in an underground way) since its origins..$^{43}$

\section{THE EGO IN PIECES}

The case of Felida $\mathrm{X}$ and the phenomenon of split personality - topics which have been increasingly studied in recent years - allow us to understand how the attempt at identifying a clear demarcation line between normality and pathology was destined not to survive scholarly confrontations over a dimension of human psyche which had previously been unknown. ${ }^{44} \mathrm{~A}$ dimension that seemed to challenge the idea of oneness of the Ego - and not only in cases of obvious mental illness - as well as the predominance of the conscious activity in human behaviour. In other words, a new way of conceiving the mind was emerging, based on the dual nature of conscious and unconscious psychological processes. This was a way of thinking about the mind that had already had philosophical manifestations in the doctrines of Schopenauer and Hartmann. ${ }^{45}$

Regarding this 'fragmentation' of the Ego, the studies done by Théodule Ribot at the end of nineteenth century seemed to show the existence of the human mind coinceived as an unsettled whole of elements and functions, potentially independent and continuously threatened by a loss of balance, which is a prelude to mental illness. In his essay concerning the Maladies de la personalité (published in the 1885) the French psychologist severely criticized the philosophical conception of the soul's oneness and the idea of its separation from the body. According to Ribot, personality was nothing but a combination of elements in a state of flux, and this gave to the Ego the inconstancy and variability of the living being. ${ }^{46}$

Phenomena like the change of personality or hypnosis allowed us to see how small the difference was between the pathological and normal condition, which both could be ruled by non-conscious processes. This was the conclusion, for instance, that the later Nobel prize-winner for medicine, Charles Richet, had reached. ${ }^{47}$ Gabriel Tarde himself - who always showed a great interest in these topics - did not fail to stress the possible repercussions that this new model of the human mind, proposed by a significant sector of nineteenth-century medicine, could produce in relation to criminal liability. ${ }^{48}$ The discovery of multiple personalities caught the imagination of the scientists at that time so much as to push both young researchers into this field of

43 On Esquirol's intuition, later denied in occasion of some sensational judicial vicissitudes, see Gauchet (1997, pp. 35sq.) On this subject see also Galzigna (2008, pp. IX-XXXI).

44 Jacqueline Carroy speaks about the "subject invention" as a condition of existence of the psychology considered as a new autonomous science (Carroy, 1991).

45 Ellenberger (1976, vol. 1, p. 366). An interesting point of view about the 'discovery' of the unconscious and the loss of the unity of the Ego (dated back, according to this author, to some intuitions of Jean Pierre Farlet) is offered by Gauchet (1997, pp. 39sq.).

46 Babini (1996, p. 30).

47 Richet (1884).

48 Tarde (1889, 2, pp. 449-469). On this subject see Chertok, De Saussure (1975, p. 210). 
research, like Pierre Janet in France ${ }^{49}$ or Max Dessoir in Germany ${ }^{50}$, and well-known scholars such as Alfred Binet, for whom in the case of split personality the subject lost his own consciousness and responsibility to become a kind of automaton, a blind tool in the hands of his brain..$^{51}$

The explanation given for these phenomena oscilated between two interpretive lines. Initially they advanced the hypothesis that every person was occupied by different personalities, but this position lost influence over the years. In the theory of Jules Janet ${ }^{52}$ for instance - who had examined the case of Blanche Witt, a hysteric with a split personality - everyone was endowed with a double Ego. The healthy state was characterized by a condition of equilibrium in which the underground personality was not able to prevail. If this equilibrium vanished - this might be for several reasons such as the onset of an illness - the second personality could surface forcefully; and so, according to Jules Janet, the second Ego, taking advantage of the weakness of the first personality, could catch a train, go to London and kill a man without his first personality having any memory of it. ${ }^{53}$ But the hypothesis of Pierre Janet (Jules's brother, destined to greater fame) had greater credit. For Janet, some psychic automatisms existed in all persons, outside the control of consciousness, and under particular circumstances they could enter into action in the life of every individual, and determine his behavior. ${ }^{54}$

According to both hypotheses they assumed that a certain degree of mental break-up was constantly present in the life of every man, even if it remained difficult to establish when this break-up might give rise to a real split in the personality. ${ }^{55}$ Thus, the idea of the existence of a subconscious level inside every person, which is able to generate impulses outside the control of consciousness, seemed to break up the reassuring unitary view of the human psyche. From the legal point of view it was impossible not to consider "cette rupture de l'unité du moi pour la délimitation de la responsabilité morale". ${ }^{56}$

Among legal scholars, the idea of the existence of different psychological forces which were not controlled by a person, whether healthy or ill, could not be easily accepted. ${ }^{57}$ Medicine and law were only able to speak the same language if they made reference to an identical view of the human being. The unity of the Ego and the dominance of consciousness had represented, until then, a shared anthropological model. Only within the parametres of this model could a suitable answer be obtained to the request made to psychiatric experts by judges to locate, through the dichotomy normality/madness, the dividing line between criminal liability/ or unaccountability. From this point of view the 'discovery' of new pathologies such as monomania and moral insanity (with their claim to pathologize the volitive function in human behavior) had stretched the boundaries to breaking point, within which law could

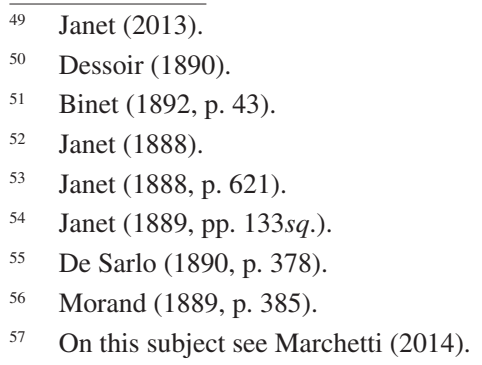


accept the new course of modern psychiatry in the courtrooms. However, the discovery of a new unconscious dimension in the psychological activity in human beings inevitably collided with the view of a person who is able to determine his own actions with consciousness, to whom law, in its punitive claim, had always made reference. ${ }^{58}$

\author{
Paolo Marchetti \\ Università degli Studi di Teramo \\ Facoltà di Giurisprudenza \\ Via Balzarini 1 \\ I - 64100 Teramo, (TE) \\ pmarchetti@unite.it
}

\title{
REFERENCES
}

Alimena, B., I limiti e i modificatori dell'imputabilità, Torino, Bocca, 1896, 3 vols. (3).

Azam, E., Amnésie périodique, ou doublement de la vie, La Revue Scientifique de la France et de l'étranger, 1876, 5, 47, pp. 481-489.

Azam, E., Hypnotisme, double conscience et altérations de la personnalité, prefaced by Charcot, J. M., Paris, Baillière et Fils, 1887.

Babini, V. P., La responsabilità nelle malattie mentali, in Babini, V. P., Cotti, M., Minuz, F., Tagliavini, A. (eds), Tra sapere e potere. La psichiatria italiana nella seconda metà dell'Ottocento, Bologna, il Mulino, 1982, pp. 135-198.

Babini, V. P., La 'psicologia scientifica' di Théodule Ribot, in Ribot, T., Scritti psicologici (1879-1894), Bologna, Clueb, 1996, pp. 9-37.

Binet, A., Les altérations de la personnalité, Paris, Felix Alcan, 1892.

Briand, J., Manuel de médecine légale, Paris, Baillière, 1821.

Carroy, J., Hypnose, suggestion et psychologie. L'invention de sujets, Paris, Puf, 1991.

Carroy, J., Entre mémoire et oubli: les deux vies de Félida, Revue internationale de psychopathology, 1992, 5, pp. 73-80.

Carroy, J., Les personnalités doubles et multiples. Entre science et fiction, Paris, Puf, 1993.

Carroy, J., Je est un autre: l'unité de moi en question au début de la $\mathrm{III}^{\mathrm{e}}$ République, in Sauvagnat F. (ed.), Divisions subjectives et personnalité multiples, Rennes, PUR, 2001, pp. 39-49.

Carroy, J., L'apparition d'un double personnalité en France. Entre médecine et philosophie, in Ehrenberg, A., Lovell, A. (eds), La maladie mentale en mutation. Psychiatrie et société, Paris, O. Jacob, 2001, pp. 43-73.

Carroy, J., L'étude des cas psychologique et psychanalytique $\left(\mathrm{XIX}^{\mathrm{e}}\right.$ siècle-début du $\mathrm{XX}^{\mathrm{e}}$ siècle), in Revel, J., Passeron, J.-C. (dir.), Penser par cas, Paris, École des Hautes Études en Sciences Sociales, 2005, pp. 201-228.

Carroy, J., Nuits savantes. Une histoire des rêves (1800-1945), Paris, EHESS, 2012.

58 The hypothesis referred to here represents one of the two extreme views of the human being which the law could not accept. The other - that does not occupy the present work - was the Lombrosian conviction of man born criminal. This idea, built as a real anthropological hypothesis more than a psychiatric one, necessarily clashed with a view of man having, if not exactly the fullness of free will, at least the opportunity to choose his own actions throughout life. 
Castel, R., L'ordine psichiatrico. L'epoca d'oro dell'alienismo, Milano, Feltrinelli, 1980 (or. L'ordre psychiatrique. L'âge d'or de l'aliénisme, Paris, Les éditions de Minuit 1977).

Chertok, L., De Saussure, R., Freud prima di Freud. Nascita della psicoanalisi, Roma-Bari, Laterza, 1975 (or. Naissance du psychanalyste De Mesmer à Freud, Paris, Payot, 1973).

Claretie, J., L'obsession. Moi et l'autre, Paris Lafitte, 1908.

De Sarlo, F., Sull'incosciente: ipnotismo, spiritualismo, lettura del pensiero, Rivista sperimentale di freniatria e medicina legale, 1890, 16, p. 352-379.

Dessoir, M., Das doppel Ich, Leipzig, E. Günter, 1890.

Dezza, E., Imputabilità e infermità mentale : la genesi dell'articolo 46 del Codice Zanardelli, Materiali per una storia della cultura giuridica, 1991, 21, 1, pp. 131-158.

Epheyre, C., Possession, Paris, Ollendorf, 1887.

Epheyre, C. [Richet, C.], Soeur Marthe, Paris, Ollendorf, 1890.

Ellenberger, H. F., La scoperta dell'inconscio. Storia della psichiatria dinamica, Torino, Bollati Boringhieri, 1976, 2 vols (1) (or. The Discovery of the Unconscious. The History and Evolution of Dynamic Psychiatry, New York, Basic Books, 1970).

Ferrari, S., Psicologia come romanzo: dalle storie di isteria agli studi sull'ipnotismo, Studi di estetica, 1985, 13, pp. 49-96.

Fodéré, F. E., Traité de médecine légale et d’hygiène publique, Paris, Mame, 1813, 6 vols., (1).

Fornari, U., Concetti vecchi e nuovi in psichiatria forense: dalla monomania al disturbo borderline di personalità, Rivista sperimentale di freniatria, 1988, 112, 6, pp. 1257-1270.

Fornari, U., Monomania omicida. Origini ed evoluzione storica del reato d'impeto, Torino, Centro Scientifico Editore, 1997.

Fornari, U., Trattato di psichiatria forense, $4^{\text {th }}$ ed., Torino, Utet, 2008.

Foucault, M., Gli anormali, Corso al Collège de France (1974-1975), Milano, Feltrinelli, 2007 (or. Les anormaux. Cours au Collège de France 1974-1975, Paris, Seuil/Gallimard, 1999).

Galzigna, M., Gli infortuni della libertà, introduction to Georget, E. J. (1826), Il crimine e la colpa. Discussione medico legale sulla follia, $2^{\text {th }}$ ed. Milano, Marsilio, 2008, pp. IXXXXIX.

Gauchet, M., De Pinel à Freud, in Swain, G., Le sujet de la folie: naissance de la psychiatrie, Paris, Calmann-Lévy, 1997, pp. 7-57.

Gilles de la Tourette, G., L'Hypnotisme et les états analogues au point de vue médico-légal, $2^{\text {th }}$ ed., Paris, Plon, 1889.

Hacking, I., La riscoperta dell'anima. Personalità multipla e scienza della memoria, Milano, Feltrinelli, 1996 (or. Rewriting the Soul: Multiple Personality and the Science of Memory, Princeton, Princeton University Press, 1995).

Harris, R., Murder and Madness: Medicine, Law and Society in the Fin de Siècle, Oxford, Clarendon Press, 1988.

Hennique, L., Minnie Brandon, Paris, Fasquelle, 1899.

Herdman, J., The Double in Nineteenth-Century Fiction, London, Mcmillan, 1990

Hoffbauer, J. C., Médicine légale relative aux aliénés et aux sourds-muets, Fr. ed., Paris, Baillière, 1827.

Krafft-Ebing, R. von, Trattato di psicopatologia forense, It. ed., Torino, Fratelli Bocca, 1897.

James T., Dream, Creativity and Madness in Nineteenth-Century France, Oxford, Clarendon, 1995.

Janet, J., L'hystérie et l'hypnose d'après la théorie de la double personnalité, Revue scientifique, $1888,25,15$, pp. 616-623. 
Janet, P., L'automatismo psicologico. Saggio sperimentale sulle forme inferiori dell'attività umana, Milano, Raffaello Cortina, 2013 (or. L'automatisme psychologique, Paris, Alcan, 1889).

Lapponi, G., Di un caso di omicidio in sonnambulismo: studio medico-legale, Bologna, Gamberini e Parmeggiani, 1883.

Liégeois, J., De la suggestion et somnambulisme dans leurs rapports avec la jurisprudence et la médicine légale, Paris, Doin, 1889.

Lindau, P., Der Andere, New York, Goldmann, 1893.

Livi, C., Della monomania in relazione col foro criminale, Rivista sperimentale di freniatria, 1876, 2, pp. 394-415 and 639-660.

Livi, C., Osservazioni critiche sul progetto di nuovo codice penale, Rivista sperimentale di freniatria, 1877, 3, pp. 120-130.

Marchetti, P., Le "sentinelle del male". L'invenzione ottocentesca del criminale nemico della società tra naturalismo giuridico e normativismo psichiatrico, Quaderni fiorentini per la storia del pensiero giuridico moderno, 2009, 38, 2, pp. 1009-1080.

Marchetti, P., Cesare Lombroso in Enciclopedia Italiana di Scienze, Lettere ed Arti. Il contributo italiano alla storia del pensiero, Ottava Appendice, Diritto, Roma, Istituto dell'Enciclopedia Treccani, 2012a, pp. 366-370.

Marchetti, P., Cesare Lombroso e l'Archivio di psichiatria, in Lacché L., Stronati M. (eds), La 'cultura' delle Riviste nel dibattito penalistico tra Otto e Novecento, Macerata, Eum, 2012b, pp. 69-96.

Marchetti, P., L'Inconscio in tribunale. Azioni incoscienti e diritto penale. Da Charcot alle neuroscienze, Milano, Franco Angeli, 2014.

Mesnet, E., Étude medico-légale sur le somnambulisme spontané et le somnambulisme provoqué, Paris, G. Masson, 1887 (published also in Revue de l'hypnotisme, 16, 1887).

Mintorn, W., Le somnambule, Paris, Ghio 1880.

Morand, J. S., Le magnétisme animal (hypnotisme et suggestion). Étude historique et critique, Paris, Garnier, 1889.

Motet, A., Accès de somnambulisme spontané et provoqué, Annales d'hygiène et de médicine légale, 1881, 5, pp. 214-225.

Revel, J., Passeron, J.-C. (dir.), Penser par cas, Paris, École des Hautes Études en Sciences Sociales, 2005.

Richet, Ch., L'homme et l'intelligence, Paris, Alcan, 1884.

Sbriccoli, M., Caratteri originari e tratti permanenti del sistema penale italiano (1860-1900), in Violante, L. (ed.), Storia d'Italia, Annali, vol. XIV, Torino, Einaudi, 1998, pp. 487-551.

Tamassia, A., Il nuovo codice penale italiano e la pazzia parziale, Rivista sperimentale di freniatria, 1876, 2, pp. 177-206.

Schönert, J., Imm, K., Linder, J. (eds), Erzahlte Kriminalitat: zur Typologie und Funktion von narrativen Darstellungen in Strafrechtspflege, Publizistik und Literatur zwischen 1770 und 1920, Tubingen, Niemeyer, 1991.

Tarde, G., Le crime et l'épilepsie, Revue philosophique de la France et de l'étranger, 1889, 2, pp. 449-469.

Tissot, C. J., Le droit pénal, Paris, Cotillon, 1860, 2 vols. (1). 